\title{
The Effect of Haematin and Catalase on Streptococcus faecalis var. zymogenes Growing on Glycerol
}

\author{
By DOROTHY J. CLARKE AND CHRISTOPHER J. KNOWLES* \\ Biological Laboratory, University of Kent, Canterbury CT2 $7 \mathrm{NJ}$
}

(Received 2 June 1980)

\begin{abstract}
Streptococcus faecalis var. zymogenes was grown aerobically on a complex medium containing glycerol as the carbon source. Addition of haematin or bovine liver catalase to the growth medium resulted in a small increment in growth yield. Suspensions of bacteria that had been grown in the presence of haematin or catalase, respectively, translocated 0.83 to 1.98 and 1.33 to 2.53 protons per oxygen atom consumed in glycerol oxidation. Bacteria grown without haematin or catalase had nil or little respiratory-induced proton translocation during glycerol oxidation. Inclusion of haematin in the growth medium caused the bacterium to form a cyanide- and azide-sensitive catalase. Superoxide dismutase activity was similar whether or not haematin was added to the growth medium.
\end{abstract}

\section{INTRODUCTION}

Although most bacteria that form cytochromes, catalase and other haemoproteins can synthesize both the apoenzymes and their haem-prosthetic groups, some organisms lack the ability to make protohaem (Knowles, 1980). Thus, they are unable to form catalase or a cytochrome-containing respiratory system unless they are provided with exogenous haematin or, in some instances, a precursor of protohaem or a haemoprotein.

The lactic acid bacteria are usually considered to conserve energy by substrate-level phosphorylation, whether growing aerobically or anaerobically. Most lactic acid bacteria are also thought to be catalase-negative. However, addition of haematin or haemoglobin to the growth medium enables a few species to form catalase and cytochromes (Whittenbury, 1960, 1964; Bryan-Jones \& Whittenbury, 1969; Sijpesteijn, 1970; Van der Wiel-Korstanjee \& De Vries, 1973; Ritchey \& Seeley, 1974, 1976; Pritchard \& Wimpenny, 1978).

We have studied the effect of including haematin in the growth medium on the formation of catalase, respiratory activity and respiratory-driven proton translocation by Streptococcus faecalis var. zymogenes grown aerobically with glycerol as the carbon source.

\section{METHODS}

Organism and growth. Streptococcus faecalis var. zymogenes strain TR was provided by Professor R. Whittenbury, University of Warwick, Coventry. This is the strain used previously by Ritchey \& Seeley (1974). It was maintained on a medium containing $\left(\mathrm{g} \mathrm{l}^{-1}\right)$ : tryptone, 10 ; yeast extract, 5 ; glucose, $4 ; \mathrm{K}_{2} \mathrm{HPO}_{4}$, 3; purified agar, 15. It was grown on medium containing $\left(\mathrm{g} \mathrm{l}^{-1}\right)$ : tryptone, $2 \cdot 5$; yeast extract, $2 \cdot 5 ; \mathrm{KH}_{2} \mathrm{PO}_{4}$, $3 \cdot 5 ; \mathrm{K}_{2} \mathrm{HPO}_{4}, 6$. The medium was adjusted to $\mathrm{pH} 6.5$ with $\mathrm{H}_{2} \mathrm{SO}_{4}$ prior to heat-sterilization at $121{ }^{\circ} \mathrm{C}$. The carbon source, glycerol, was prepared as a $0.5 \mathrm{M}$ stock solution, sterilized at $121{ }^{\circ} \mathrm{C}$ and added aseptically to give $8 \mathrm{~mm}$ in the growth medium. Haematin $\left(5 \mathrm{mg} \mathrm{ml}^{-1}\right.$ in $\left.0.02 \mathrm{M}-\mathrm{KOH}\right)$ was sterilized by membranefiltration $\left(0.45 \mu \mathrm{m}\right.$ pore size), stored at $4{ }^{\circ} \mathrm{C}$ and added, where indicated, to the growth medium to give $10 \mu \mathrm{g} \mathrm{ml}^{-1}$. Catalase was prepared as a $3 \mathrm{mg} \mathrm{ml}^{-1}$ stock solution, sterilized by membrane-filtration and added, where indicated, to the growth medium to give $6 \mu \mathrm{g} \mathrm{ml}^{-1}$. For media containing additional trace metals, a stock solution was prepared according to Bauchop \& Elsden (1960), heat-sterilized at $121{ }^{\circ} \mathrm{C}$ and added to the medium at $5 \mathrm{ml} \mathrm{l}^{-1}$. The organism was grown aerobically in an orbital incubator (200 rev. $\left.\mathrm{min}^{-1}\right)$ 
at $35^{\circ} \mathrm{C}$. Cultures used as inocula contained $50 \mathrm{ml}$ medium in $250 \mathrm{ml}$ conical flasks; growth cultures contained $500 \mathrm{ml}$ medium in 21 conical flasks. A $2 \%(\mathrm{v} / \mathrm{v})$ inoculum of a culture grown for $16 \mathrm{~h}$ was used to initiate growth. To establish culture purity, samples were examined by plating, microscopy, the oxidase test (negative) and the catalase test (negative, when plated in the absence of haematin).

Determination of dry weight. Duplicate cultures were grown for $16 \mathrm{~h}$ in a medium containing haematin and 0,5 or $10 \mathrm{~mm}$-glycerol. They were harvested, washed twice in distilled water and centrifuged $(23000 \mathrm{~g}$, $10 \mathrm{~min})$, then dried at $100^{\circ} \mathrm{C}$ to constant weight. Growth was estimated turbidimetrically at $680 \mathrm{~nm}(1 \mathrm{~cm}$ light path); an absorbance of 1.0 was equivalent to $310 \mu \mathrm{g}$ dry wt $\mathrm{ml}^{-1}$.

Determination of protein. The method of Lowry was used and the absorbance was measured at $500 \mathrm{~nm}$. Bovine serum albumin was used as a standard. Samples were diluted 25 -fold to minimize interference by haematin.

Estimation of $\mathrm{H}_{2} \mathrm{O}_{2}$ in the growth medium. Samples of the growth medium were removed from the growth vessel, centrifuged $(2500 \mathrm{~g}, 5 \mathrm{~min})$ and diluted as required. $\mathrm{H}_{2} \mathrm{O}_{2}$ in the samples was assayed polarographically in a Clark-type oxygen electrode (Rank Bros., Bottisham, Cambs.) by measuring the dissolved $\mathbf{O}_{2}$ content at $35^{\circ} \mathrm{C}$ upon adding catalase, as described by Dempsey et al. (1975). The response of the electrode was calibrated using solutions of $\mathrm{H}_{2} \mathrm{O}_{2}$ in $60 \mathrm{~mm}-\mathrm{Na}^{+} / \mathrm{K}^{+}$phosphate buffer, $\mathrm{pH} 6.5$ that had been standardized by titration against a $\mathrm{KMnO}_{4}$ solution.

Oxygen uptake. Bacteria were harvested by centrifugation $\left(23000 \mathrm{~g}, 10 \mathrm{~min}, 4^{\circ} \mathrm{C}\right)$ and washed twice in $50 \mathrm{mM}-\mathrm{KH}_{2} \mathrm{PO}_{4} / \mathrm{K}_{2} \mathrm{HPO}_{4}$ buffer, $\mathrm{pH} 6.5$. The bacteria were resuspended in the same buffer to a density of approx. $0.4 \mathrm{mg} \mathrm{dry} \mathrm{wt} \mathrm{ml}^{-1}$ for bacteria grown to the mid-exponential phase. $\mathrm{O}_{2}$ uptake by a $3 \mathrm{ml}$ sample of resuspended bacteria was determined in an oxygen electrode at $35^{\circ} \mathrm{C}$. Oxidation rates for endogenous substrates, glycerol, glucose and lactate were measured; exogenous substrates were added to give $33 \mathrm{~mm}$. The solubility of $\mathrm{O}_{2}$ was assumed to be $0.41 \mu \mathrm{mol} \mathrm{O} \mathrm{ml}{ }^{-1}$ at $35^{\circ} \mathrm{C}$ (Chappell, 1964).

Proton-pulse measurement. Proton-pulses were measured by injecting air-saturated $\mathrm{KCl}$ into an anaerobic suspension of bacteria in the presence of $\mathrm{KSCN}$ and measuring the resultant $\mathrm{pH}$ change. The technique used was an adaptation of that described by Mitchell \& Moyle $(1967 a, b)$. Bacteria were harvested by centrifuging $\left(23000 \mathrm{~g}, 10 \mathrm{~min}, 4^{\circ} \mathrm{C}\right)$ and washed twice in buffer $(200 \mathrm{mM}-\mathrm{KCl} / 2 \mathrm{mM}$-glycylglycine/HCl, pH 6.5) with centrifugation $\left(38000 \mathrm{~g}, 5 \mathrm{~min}, 4^{\circ} \mathrm{C}\right)$. The bacteria were resuspended in $150 \mathrm{~mm}-\mathrm{KSCN} / 50 \mathrm{~mm}-\mathrm{KCl} / 1 \mathrm{~mm}-$ glycylglycine/ $\mathrm{HCl}, \mathrm{pH} 6.5$ to about $3 \mathrm{mg}$ dry wt $\mathrm{ml}^{-1}$. The $\mathrm{KSCN}$ concentration and buffer conditions given are those determined for optimum proton-pulses. The suspension was pipetted into a water-jacketed glass chamber maintained at $35^{\circ} \mathrm{C}$, and stirred by a magnetic stirrer and bar. A rapid-response combination glass/reference pH probe (CMAJ 72, Russell pH Ltd, Auchtermuchty, Fife) was inserted into the suspension. The completely filled chamber was sealed with Parafilm such that no air was trapped above the suspension, and a stream of $\mathrm{O}_{2}$-free $\mathrm{N}_{2}$ was blown over the seal. The $\mathrm{pH}$ probe was connected to a Pye model $290 \mathrm{pH}$ meter with scale expansion (Pye Unicam). The output was passed through a back-off circuit to a chart recorder (Kipp \& Zonen BD8 multirange recorder). A preincubation period of 45 to $60 \mathrm{~min}$ was required for minimal pH drift. Substrates (see Table 2) were added to give $8 \mathrm{~mm}$, and a further $10 \mathrm{~min}$ was allowed for $\mathrm{pH}$ stabilization. Pulses of air-saturated $200 \mathrm{mM}-\mathrm{KCl}(5$ to $50 \mu \mathrm{l})$ were added through the seal by means of a $50 \mu \mathrm{l}$ micro-syringe and the change in $\mathrm{pH}$ was measured. Injections of $5 \mu \mathrm{l}$ anaerobic $4 \mathrm{~mm}-\mathrm{NaOH}$ were used to calibrate the pulses. The maximum observed change in $\mathrm{pH}$ was used to determine the $\rightarrow \mathrm{H}^{+} / \mathrm{O}$ ratio. Correction by extrapolation back to zero time for the proton-pulses (Mitchell \& Moyle, 1967 $a, b$ ) and the anaerobic $\mathrm{NaOH}$ injections had only a negligible effect on the measured $\rightarrow \mathrm{H}^{+} / \mathrm{O}$ ratios. Dissipation of proton pulses was examined by addition of carbonyl cyanide $m$-chlorophenylhydrazone (CCCP) in ethanol to give $10 \mu \mathrm{M}$.

Preparation of cell-free extracts. Bacteria grown to the mid-exponential phase were harvested by centrifugation $\left(23000 \mathrm{~g}, 10 \mathrm{~min}, 4^{\circ} \mathrm{C}\right)$ and washed once in the buffer used for the enzyme measurements. Cells were disrupted ultrasonically $(8 \times 30 \mathrm{~s}$ using an $150 \mathrm{~W}$ MSE ultrasonic disintegrator at maximum power), and cell debris was removed by centrifugation $\left(12000 \mathrm{~g}, 10 \mathrm{~min}, 4^{\circ} \mathrm{C}\right)$.

Determination of catalase activity (EC 1.11.1.6). Cell-free extract $(0.2 \mathrm{ml})$ was incubated at $35^{\circ} \mathrm{C}$ with $1.8 \mathrm{ml} 50 \mathrm{~mm}$-morpholinopropanesulphonic acid buffer (MOPS), $\mathrm{pH} 7.5$ containing $70 \mathrm{mM}-\mathrm{H}_{2} \mathrm{O}_{2}$ for 0,15 , 30 and $60 \mathrm{~s}$. The reaction was stopped by adding $0.25 \mathrm{ml} \mathrm{Ti}\left(\mathrm{SO}_{4}\right)_{2}$ reagent. This reagent was prepared by diluting $\mathrm{Ti}\left(\mathrm{SO}_{4}\right)_{2}$ solution $\left[15 \%\right.$ (w/v) in $\left.23 \%(\mathrm{w} / \mathrm{v}) \mathrm{H}_{2} \mathrm{SO}_{4}\right]$ with $1 \mathrm{M}-\mathrm{H}_{2} \mathrm{SO}_{4}(1: 1, \mathrm{v} / \mathrm{v})$. Precipitated protein was removed by centrifuging at $2500 \mathrm{~g}$ for $5 \mathrm{~min}$. The solutions were diluted as appropriate with $1 \mathrm{M}$ $\mathrm{H}_{2} \mathrm{SO}_{4}$, and the absorbance was measured at $420 \mathrm{~nm}$. A calibration curve for the $\mathrm{Ti}\left(\mathrm{SO}_{4}\right)_{2}$ reagent was prepared using $\mathrm{H}_{2} \mathrm{O}_{2}$ in $50 \mathrm{mM}-\mathrm{MOPS}$, $\mathrm{pH} 7.5\left(0\right.$ to $\left.1250 \mathrm{nmol} \mathrm{H}_{2} \mathrm{O}_{2} \mathrm{ml}^{-1}\right)$ standardized by titration against a $\mathrm{KMnO}_{4}$ solution (Snell \& Snell, 1949). Catalase activity was expressed as the initial rate of $\mathrm{H}_{2} \mathrm{O}_{2}$ cleavage.

Determination of superoxide dismutase activity (EC 1.15.1.1). The method of McCord \& Fridovich (1969) was used. The cytochrome $c$ concentration was increased to $10 \mu \mathrm{M}$ to increase reproducibility, and the reaction was assayed at $35^{\circ} \mathrm{C}$. The assay mixture contained $50 \mathrm{mM}-\mathrm{KH}_{2} \mathrm{PO}_{4} / \mathrm{K}_{2} \mathrm{HPO}_{4}$ buffer, pH 7.8, $10 \mu \mathrm{M}$ - 

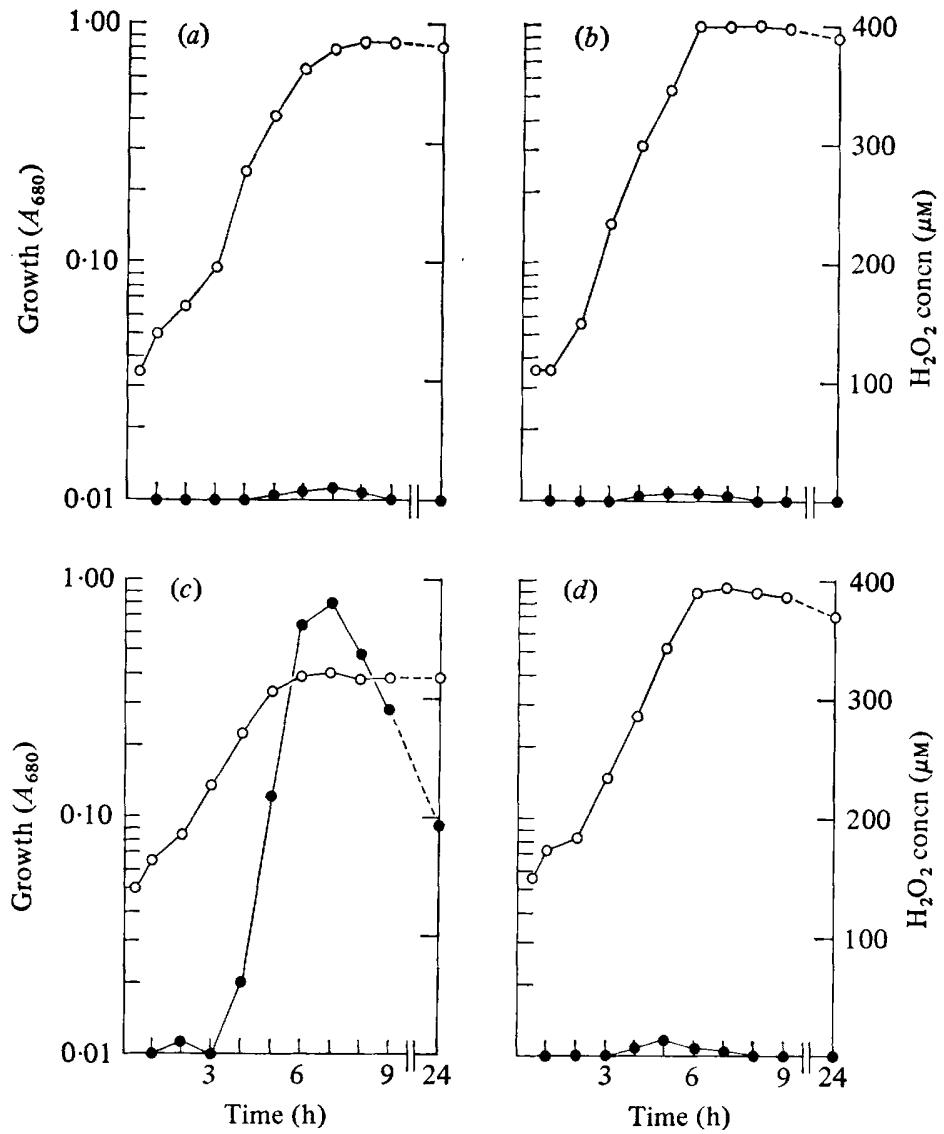

Fig. 1. Effect of the inclusion of haematin in the medium on growth and $\mathrm{H}_{2} \mathrm{O}_{2}$ accumulation. Streptococcus faecalis var, zymogenes was grown in a complex medium containing $8 \mathrm{~mm}$-glycerol. Growth $(\mathrm{O})$ and $\mathrm{H}_{2} \mathrm{O}_{2}$ accumulation in the medium (O) are shown for cultures grown in the absence of haematin $(a, c)$, and in the presence of $10 \mu \mathrm{g}$ haematin $\mathrm{ml}^{-1}(b, d)$. Additional trace metals (see Methods) were present in $(c)$ and $(d)$.

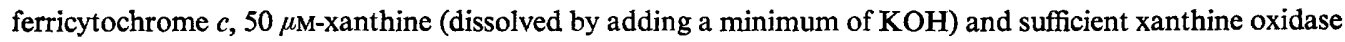
to result in an increase in absorbance at $550 \mathrm{~nm}$ of $0.025 \mathrm{~min}^{-1}$. Cell-free extract ( 0 to $200 \mu \mathrm{g}$ protein) was added to the assay mixture and a graph of the activity ( $\%$ ) against protein concentration was plotted. One unit of superoxide dismutase activity was defined as the concentration of enzyme required to inhibit the reduction of ferricytochrome $c$ at $35^{\circ} \mathrm{C}$ by $50 \%$.

Chemicals. Tryptone, yeast extract and purified agar were obtained from Oxoid. Titanium sulphate solution $\left(15 \%(\mathrm{w} / \mathrm{v})\right.$ in $23 \%(\mathrm{w} / \mathrm{v}) \mathrm{H}_{2} \mathrm{SO}_{4}$, technical grade) was obtained from $\mathrm{BDH}$. Haematin, bovine liver catalase, bovine serum albumin, ferricytochrome $c$ (type III), xanthine oxidase (Grade I, from buttermilk), and all other chemicals were obtained from Sigma or Fisons. Glass-distilled water was used throughout.

\section{RESULTS}

Addition of haematin at $10 \mu \mathrm{g} \mathrm{ml}^{-1}$ slightly increased the growth of $S$. faecalis (Fig. $1 a, b$ ). $\mathrm{H}_{2} \mathrm{O}_{2}$ was detectable at only very low concentrations in the medium, whether haematin was present or not. When trace metals were added to the medium, the difference in growth yields in the presence and absence of haematin was very marked (Fig. $1 c, d$ ). This was due to a decreased growth yield in the absence of haematin and was accompanied by production of up to $400 \mu \mathrm{M}-\mathrm{H}_{2} \mathrm{O}_{2}$ by the time the late-exponential growth phase was reached. The $\mathrm{H}_{2} \mathrm{O}_{2}$ produced during growth in the presence of trace metals and in the absence of haematin 
Table 1. Activities of substrate oxidases for bacteria grown to the mid-exponential phase on $8 \mathrm{mM}-\mathrm{glycerol}$ in the presence and absence of haematin or catalase

Substrate $(0.1 \mathrm{ml}$ of a $1 \mathrm{M}$ solution) was added to $2.9 \mathrm{ml}$ resuspended bacteria in 50 mM-phosphate buffer, pH 6.5. Oxidase activities are shown as the mean \pm s.D. (no. of observations).

\begin{tabular}{cccc} 
& \multicolumn{3}{c}{ Oxidase activity [nmol O $\mathrm{min}^{-1}\left(\mathrm{mg} \mathrm{dry} \mathrm{wt}^{-1}\right.$ ] } \\
Substrate oxidized & $\begin{array}{c}\text { Bacteria grown } \\
\text { without haematin } \\
\text { or catalase }\end{array}$ & $\begin{array}{c}\text { Bacteria grown } \\
\text { with haematin } \\
\left(10 \mu \mathrm{g} \mathrm{ml}^{-1}\right)\end{array}$ & $\begin{array}{c}\text { Bacteria grown } \\
\text { with catalase } \\
\left(6 \mu \mathrm{g} \mathrm{ml}^{-1}\right)\end{array}$ \\
Endogenous & $9 \pm 12(10)$ & $10 \pm 11(12)$ & $4 \pm 3(12)$ \\
Glycerol & $411 \pm 60(10)$ & $509 \pm 101(12)$ & $376 \pm 161(12)$ \\
Glucose & $148 \pm 67(10)$ & $219 \pm 28(12)$ & $175 \pm 46(12)$ \\
Lactate & $231 \pm 96(10)$ & $241 \pm 93(12)$ & $129 \pm 65(12)$
\end{tabular}

Table 2. Oxygen-induced proton-pulses by bacteria grown to the mid-exponential phase

The results are expressed as $\rightarrow \mathrm{H}^{+} / \mathrm{O}$ ratios and are shown as the mean \pm S.D. (no. of observations) for each batch of bacteria.

\begin{tabular}{|c|c|c|c|}
\hline \multirow{2}{*}{$\begin{array}{c}\text { Incubation substrate } \\
\text { Endogenous }\end{array}$} & \multicolumn{3}{|c|}{$\rightarrow \mathrm{H}^{+} / \mathrm{O}$ ratio } \\
\hline & $\begin{array}{l}\text { Bacteria grown } \\
\text { without haematin } \\
\text { or catalase }\end{array}$ & $\begin{array}{c}\text { Bacteria grown } \\
\text { with haematin } \\
\left(10 \mu \mathrm{g} \mathrm{ml}^{-1}\right)\end{array}$ & $\begin{array}{l}\text { Bacteria grown } \\
\text { with catalase } \\
\left(6 \mu \mathrm{g} \mathrm{ml}^{-1}\right)\end{array}$ \\
\hline Endogenous & $\begin{array}{l}0(5) \\
0(5) \\
0(5)\end{array}$ & $\begin{array}{l}0(5) \\
0(5) \\
0(5)\end{array}$ & $\begin{array}{c}1.67 \pm 0.20 \\
2.27 \pm 0.39(10) \\
0(5) \\
0(5)\end{array}$ \\
\hline Glycerol & $\begin{array}{c}0(5) \\
0(5) \\
0 \cdot 31 \pm 0 \cdot 26(10)\end{array}$ & $\begin{array}{l}1.05 \pm 0.09(10) \\
0.83 \pm 0.09(11) \\
1.98 \pm 0.16(10)\end{array}$ & $\begin{array}{l}1.33 \pm 0.04 \\
2.53 \pm 0.56 \\
1.71 \pm 0.10(1) \\
2.00 \pm 0.19(12)\end{array}$ \\
\hline Glucose & $\begin{array}{l}0(5) \\
0(5)\end{array}$ & $0(5)$ & $1 \cdot 06 \pm 0 \cdot 10(10)$ \\
\hline Lactate & $\begin{array}{c}0(5) \\
0 \cdot 15 \pm 0 \cdot 23(10)\end{array}$ & $0(5)$ & $2 \cdot 28 \pm 0.37$ \\
\hline
\end{tabular}

was somewhat variable but was much greater than found under the other growth conditions. When catalase $\left(6 \mu \mathrm{g} \mathrm{ml}^{-1}\right)$ was added to cultures as an alternative haem source which would also be able to remove $\mathrm{H}_{2} \mathrm{O}_{2}$, the growth yields were similar to those obtained with haematin, with nil or very low concentrations of $\mathrm{H}_{2} \mathrm{O}_{2}$ in the medium.

Respiratory activities were low with endogenous substrates for bacteria cultured with or without a haem source and harvested in the mid-exponential phase of growth (Table 1). Compared with bacteria grown without a haem source, haematin-grown bacteria showed increased oxidation rates for glycerol and glucose as substrates. Bacteria grown in the presence of catalase had increased rates of oxidation of glucose but a lower rate of oxidation of lactate. For bacteria harvested in the stationary phase $(16 \mathrm{~h})$ nil or only a very low oxidase activity was observed for glycerol 3-phosphate, pyruvate, succinate, malate, citrate, isocitrate, fructose 1,6-bisphosphate, ascorbate plus $N, N, N^{\prime}, N^{\prime}$-tetramethyl-p-phenylenediamine, and ascorbate plus phenazine methosulphate.

The results obtained for oxygen-induced proton-pulses are shown in Table 2. Oxygeninduced proton extrusion was detected with glycerol as substrate for bacteria grown in the presence of haematin or catalase. Proton-pulses were also observed for oxidation of endogenous substrates, glucose and lactate by bacteria grown in the presence of catalase. Where proton-pulses were detected, additions of anaerobic $\mathrm{KCl}$ did not cause any acidification of the medium, and addition of $10 \mu \mathrm{M}-\mathrm{CCCP}$ collapsed the proton-pulses $\left(\rightarrow \mathrm{H}^{+} / \mathrm{O}=0\right)$. Low 
Table 3. Catalase activity of cell-free extracts from bacteria grown to the mid-exponential phase

Catalase activities are expressed as the initial rate of $\mathrm{H}_{2} \mathrm{O}_{2}$ cleavage and are shown as the mean \pm S.D. (no. of observations) for each batch of bacteria.

Catalase activity

[ $\mu \mathrm{mol} \mathrm{H}_{2} \mathrm{O}_{2}$ cleaved $\mathrm{min}^{-1}(\mathrm{mg} \text { protein })^{-1}$ ]

\begin{tabular}{|c|c|c|}
\hline & $\begin{array}{l}\text { Bacteria grown } \\
\text { without haematin }\end{array}$ & $\begin{array}{l}\text { Bacteria grown } \\
\text { with haematin } \\
\left(10 \mu \mathrm{g} \mathrm{ml}^{-1}\right)\end{array}$ \\
\hline Bacteria grown without additional trace metals & $\begin{array}{c}0(5) \\
5 \cdot 5 \pm 3 \cdot 5(5)\end{array}$ & $\begin{array}{r}69 \cdot 5 \pm 14 \cdot 5(5) \\
108 \cdot 5 \pm 9 \cdot 0(5) \\
105 \cdot 0 \pm 5 \cdot 5(5)\end{array}$ \\
\hline Bacteria grown with additional trace metals & $\begin{array}{l}4 \cdot 0 \pm 6 \cdot 5(5) \\
5 \cdot 0 \pm 2 \cdot 0(5)\end{array}$ & $\begin{array}{l}62 \cdot 5 \pm 2 \cdot 5(5) \\
58 \cdot 5 \pm 4 \cdot 5(5) \\
53 \cdot 5 \pm 4 \cdot 5(5)\end{array}$ \\
\hline
\end{tabular}

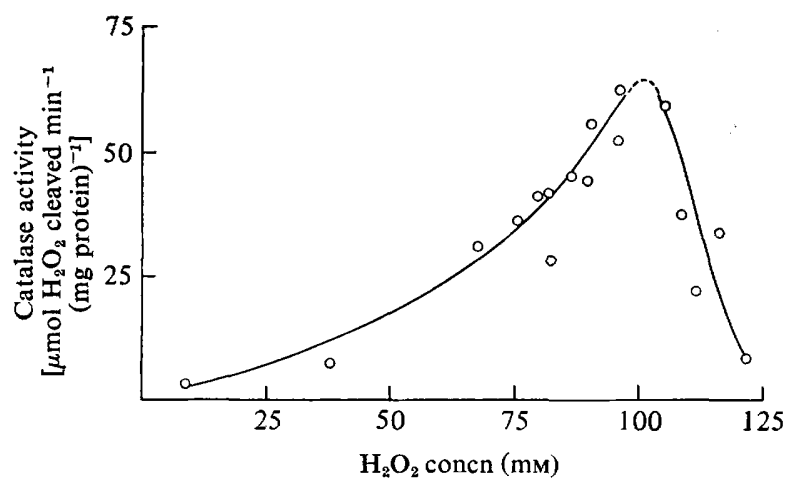

Fig. 2. Catalase activity in cell-free extracts of Streptococcus faecalis var. zymogenes grown to the stationary phase $(16 \mathrm{~h})$ in the presence of $10 \mu \mathrm{g}$ haematin $\mathrm{ml}^{-1}$, showing the relationship between catalase activity (initial rate for samples of cell-free extract containing $1 \mathrm{mg}$ protein) and $\mathrm{H}_{2} \mathrm{O}_{2}$ concentration.

$\rightarrow \mathrm{H}^{+} / \mathrm{O}$ values were detected for one sample of non-haem-grown cells with glycerol and lactate as substrates. These may have been due to traces of haem in the growth medium, although in spectra of concentrated medium no haem could be detected.

The mean $\rightarrow \mathrm{H}^{+} / \mathrm{O}$ ratios for different batches of haematin-grown bacteria were 0.83 to 1.98 for glycerol oxidation. The range of mean ratios for glycerol oxidation by catalasegrown bacteria was higher (1.33 to 2.53$)$. Two batches of catalase-grown bacteria had mean $\rightarrow \mathrm{H}^{+} / \mathrm{O}$ ratios of 1.67 and 2.27 for oxidation of endogenous substrates whereas with two other batches no oxygen-induced pulses were observed. The mean $\rightarrow \mathrm{H}^{+} / \mathrm{O}$ ratio for a single batch of catalase-grown bacteria for oxidation of glucose was 1.06 and for lactate oxidation was 2-28. A suspension of bacteria grown without haematin or catalase did not show protonpulses with glycerol or endogenous substrates when catalase $\left(6 \mu \mathrm{g} \mathrm{ml}^{-1}\right)$ was added to the incubation mixture.

Cell-free extracts from bacteria grown without haematin showed a very low catalase activity compared with those grown in the presence of haematin (Table 3). Concentrations of catalase were slightly higher in haematin-containing cultures of bacteria grown without added trace metals. The catalase activity had a wide $\mathrm{pH}$ range, with a broad optimum at pH 6 to 8 , and was sensitive to cyanide and azide inhibition (50\% inhibition by 10 to $30 \mu \mathrm{M}$ cyanide or azide). The enzyme showed increasing activity with $\mathrm{H}_{2} \mathrm{O}_{2}$ up to approx. $100 \mathrm{mM}$, above which it was inactivated (Fig. 2). To compare catalase activity under the different 
growth conditions, the initial $\mathrm{H}_{2} \mathrm{O}_{2}$ concentration used was $70 \mathrm{mM}$, which was that required to give half-maximal activity.

Similar activities of superoxide dismutase were present in bacteria that had been grown to the mid-exponential phase in the presence and absence of haematin. The activities were $10 \cdot 1 \pm$ S.D. $1 \cdot 5$ (3) and $8 \cdot 8 \pm$ S.D. $0 \cdot 6(3)$ units (mg protein) ${ }^{-1}$, respectively.

\section{DISCUSSION}

During aerobic growth of $S$. faecalis the major pathway of glycerol assimilation is via conversion to glycerol 3-phosphate by glycerol kinase. Dihydroxyacetone phosphate and $\mathrm{H}_{2} \mathrm{O}_{2}$ are then formed by glycerophosphate oxidase (Jacobs \& VanDemark, $1960 a, b$; Esders \& Michina, 1979). The formation of this pathway as the major aerobic route of glycerol assimilation appears to be unaffected by inclusion of haematin in the growth medium (S. Y. R. Pugh \& C. J. Knowles, unpublished observations). Therefore, the detection of nil or little $\mathrm{H}_{2} \mathrm{O}_{2}$ in the medium during growth in the absence of extra trace metals (in the presence or absence of exogenous haematin) was presumably due to degradation of $\mathrm{H}_{2} \mathrm{O}_{2}$ by the bacterium. When haematin was not included in the medium little catalase was formed and the $\mathrm{H}_{2} \mathrm{O}_{2}$ must have been degraded by another route. The most likely method was by NADH peroxidase (Dolin, 1953, 1975, 1977; Hoskins et al., 1962):

$$
\mathrm{NADH}+\mathrm{H}^{+}+\mathrm{H}_{2} \mathrm{O}_{2} \longrightarrow \mathrm{NAD}^{+}+2 \mathrm{H}_{2} \mathrm{O}
$$

When haematin was present in the growth medium catalase was formed and $\mathrm{H}_{2} \mathrm{O}_{2}$ could have been removed by NADH peroxidase and/or catalase. Under these growth conditions $S$. faecalis forms a cytochrome-linked membrane-bound respiratory system which is able to oxidize NADH (Bryan-Jones \& Whittenbury, 1969; Ritchey \& Seeley, 1974, 1976; Pritchard \& Wimpenny, 1978). It is therefore possible that $\mathrm{H}_{2} \mathrm{O}_{2}$ was detoxified primarily by catalase and NADH was oxidized preferentially by the respiratory system.

Addition of trace metals to the growth medium resulted in $\mathrm{H}_{2} \mathrm{O}_{2}$ accumulation. Furthermore, growth was depressed, which could have been due to the toxic effects of the $\mathrm{H}_{2} \mathrm{O}_{2}$. The reasons for the appearance of $\mathrm{H}_{2} \mathrm{O}_{2}$ in the medium are not clear. One possibility is that one or more of the trace metals inhibited the NADH peroxidase activity. Metabolism could have been altered such that insufficient NADH was available for removal of $\mathrm{H}_{2} \mathrm{O}_{2}$ via the peroxidase.

Whereas most lactic acid bacteria do not exhibit any catalase-like activity, a few species form a 'pseudocatalase' (Delwiche, 1961; Johnston \& Delwiche, 1962; Whittenbury, 1960, 1964). Unlike normal haem-containing catalases, pseudocatalases have none of the absorbance peaks associated with haemoproteins. They are insensitive to azide and cyanide and are not inactivated by prolonged exposure to $\mathrm{H}_{2} \mathrm{O}_{2}$. The development of catalase activity by $S$. faecalis var. zymogenes on addition of haematin to the growth medium and its sensitivity to azide and cyanide suggests that it is a haem-containing enzyme.

Gallin \& VanDemark (1964) obtained a P/O ratio of 0.24 for oxidation of NADH by cell-free extracts of $S$. faecalis $10 \mathrm{Cl}$ grown aerobically in the absence of haematin and suggested that there was coupling of ATP synthesis to electron transport at the site 1 region. This was supported by growth yield studies (Smalley et al., 1968), but no corrections were made for the effects of changes in growth rate or maintenance energy requirements (cf. Tempest \& Neijssel, 1980). In contrast, neither Ritchey \& Seeley (1974) nor Bryan-Jones \& Whittenbury (1969) obtained evidence for oxidative phosphorylation by $S$. faecalis var. zymogenes or $S$. faecalis NCDO 581, respectively, growing in haematin-free media. A possible reason for this discrepancy is that traces of haematin or a haemoprotein could have been present in the medium or on the glassware used by Gallin \& VanDemark (1964) and Smalley et al. (1968) (see Knowles, 1980).

In order to determine if energy conservation coupled to respiration occurs in haematin- 
grown $S$. faecalis we have measured proton translocation using the technique of Mitchell \& Moyle $(1967 a, b)$. Respiratory-driven acidification of the suspension medium did not usually occur for bacteria grown in the absence of added haematin (Table 2). The low $\rightarrow \mathrm{H}^{+} / \mathrm{O}$ ratios obtained in two batches of bacteria could have been due to traces of haematin or a haemoprotein present in the complex growth medium. When the bacteria had been grown in the presence of haematin, $\rightarrow \mathrm{H}^{+} / \mathrm{O}$ ratios of 0.83 to 1.98 were obtained for oxidation of glycerol. This suggests that there was a single proton translocating loop during oxidation of glycerol. Assuming an $\rightarrow \mathrm{H}^{+} / \sim \mathrm{P}$ ratio of 2 , a single ATP molecule was formed per oxygen atom reduced (Haddock \& Jones, 1977). However, if the $\rightarrow \mathrm{H}^{+} / \sim \mathrm{P}$ ratio is higher (Brand, 1977) there would be a lower efficiency of transduction. Alternatively, the observed $\rightarrow \mathrm{H}^{+} / \mathrm{O}$ ratio could be an underestimate due to ion movements, especially of potassium (Wilson et al., 1976; Reynafarge et al., 1976).

When exogenous bovine liver catalase was used as a source of protohaem, slightly higher $\rightarrow \mathrm{H}^{+} / \mathrm{O}$ ratios were observed for glycerol oxidation. In addition, proton ejection was observed in response to oxidation of endogenous substrates by some batches of bacteria, and for oxidation of glucose or lactate. The rates of oxidation of endogenous substrates were extremely low for suspensions of bacteria grown under all three growth conditions (Table 1) and considerable difficulties were experienced in attaining complete anaerobiosis in the reaction chamber used to assay proton-pulses. In addition, in anaerobic suspensions containing lactate or glucose there was continuous acidification of the incubation mixture, making reliable measurements of the $\rightarrow \mathrm{H}^{+} / \mathrm{O}$ ratios difficult. It was only with glycerol as substrate that reasonable stability was attained.

That haematin-induced respiratory-driven energy transduction occurs in $S$. faecalis has also been shown recently by Pritchard \& Wimpenny (1978). They grew S. faecalis var. zymogenes in continuous culture on lactate, and obtained an $\rightarrow \mathrm{H}^{+} / \mathrm{O}$ ratio of 1.37 for oxidation of lactate.

Additional energy conservation by the bacterium when it was grown in the presence of haematin or catalase was also suggested by the small but definite increase in growth yield (Fig. 1). Because of other factors (Tempest \& Neijssel, 1980), interpretation of growth yield values requires more sophisticated experimentation to determine the extra energy transduction.

During aerobic growth of living cells, toxic superoxide is produced which must be removed by superoxide dismutase (Fridovich, 1978). Superoxide dismutase activity has been found in aerobically grown S. faecalis (Gregory \& Fridovich, 1973; Britton et al., 1978). Since the development of a respiratory system by $S$. faecalis was likely to result in formation of extra superoxide (Fridovich, 1978), it was possible that greater synthesis of superoxide dismutase was necessary. In fact, no overall increase in superoxide dismutase activity was found on inclusion of haematin in the growth medium, indicating that sufficient activity was already present to successfully scavenge any increases in superoxide formation.

Unlike Lactobacillus plantarum (Götz et al., 1980) the superoxide dismutase activity of $S$. faecalis var. zymogenes is probably enzymic since boiling extracts caused loss of activity. Moreover, Britton et al. (1978) have purified the enzyme from another strain of S. faecalis.

This work was supported by the Science Research Council via grant no. GR/A/38465 to C. J. Knowles. 


\section{REFERENCES}

Bauchop, T. \& Elsden, S. R. (1960). The growth of micro-organisms in relation to their energy supply. Journal of General Microbiology 23, 457-469.

Brand, M. D. (1977). The stoichiometric relationships between electron transport, proton translocation and adenosine triphosphate synthesis and hydrolysis in mitochondria. Biochemical Society Transactions 5, 1615-1620.

Britton, L., Malinowski, D. P. \& Fridovich, I. (1978). Superoxide dismutase and oxygen metabolism in Streptococcus faecalis and comparisons with other organisms. Journal of Bacteriology 134, 229-236.

Bryan-Jones, D. G. \& Whittenbury, R. (1969). Haematin-dependent oxidative phosphorylation in Streptococcus faecalis. Journal of General Microbiology 58, 247-260.

Chappell, J. B. (1964). The oxidation of citrate, isocitrate and cis-aconitate by isolated mitochondria. Biochemical Journal 90, 225-237.

Delwiche, E. A. (1961). Catalase of Pediococcus cerevisiae. Journal of Bacteriology 81, 416-418.

Dempsey, P. M., O'Leary, J. \& Condon, S. (1975). Polarographic assay of hydrogen peroxide accumulation in microbial cultures. Applied Microbiology 29, 170-174.

Dolin, M. I. (1953). The oxidation and peroxidation of $\mathrm{DPNH}_{2}$ in extracts of Streptococcus faecalis 10C1. Archives of Biochemistry and Biophysics 46, 483-484.

Dolin, M. I. (1975). Reduced diphosphopyridine nucleotide peroxidase. Intermediates formed on reduction of the enzyme with dithionite or reduced diphosphopyridine nucleotide. Journal of Biological Chemistry 250, 310-317.

DoLin, M. I. (1977). DPNH peroxidase: effector activities of $\mathrm{DPN}^{+}$. Biochemical and Biophysical Research Communications 78, 393-400.

Esders, T. W. \& Michina, C. A. (1979). Purification and properties of $\mathrm{L}-\alpha$-glycerophosphate oxidase from Streptococcus faecium ATCC 12755. Journal of Biological Chemistry 254, 2710-2715.

Fridovich, I. (1978). The biology of oxygen radicals. Science 201, 875-880.

Gallin, J. I. \& VanDemark, P. J. (1964). Evidence for oxidative phosphorylation in Streptococcus faecalis. Biochemical and Biophysical Research Communications 17, 630-635.

Götz, F., Elstner, E. F., Sedewitz, B. \& LenGFELDER, E. (1980). Oxygen utilisation by Lactobacillus plantarum. II. Superoxide and superoxide dismutation. Archives of Microbiology 125, 215220.

Gregory, E. M. \& Fridovich, I. (1973). Induction of superoxide dismutase by molecular oxygen. Journal of Bacteriology 114, 543-548.

Haddock, B. A. \& Jones, C. W. (1977). Bacterial respiration. Bacteriological Reviews 41, 47-99.

Hoskins, D. D., Whiteley, H. R. \& MackleR, B. (1962). The reduced diphosphopyridine nucleotide oxidase of Streptococcus faecalis: purification and properties. Journal of Biological Chemistry 237, 2647-2653.
Jacobs, N. J. \& VanDemark, P. J. (1960a). Comparison of the mechanism of glycerol oxidation in aerobically and anaerobically grown Streptococcus faecalis. Journal of Bacteriology 79, 532-538.

JACOBS, N. J. \& VANDemark, P. J. (1960b). The purification and properties of $\alpha$-glycerophosphateoxidising enzyme of Streptococcus faecalis $10 \mathrm{C1}$. Archives of Biochemistry and Biophysics 88, 250 255.

Johnston, M. A. \& Delwiche, E. A. (1962). Catalase of Lactobacillaceae. Journal of Bacteri$\operatorname{olog} y$ 83, 936-938.

KnOWLes, C. J. (1980). Heme-requiring bacterial respiratory systems. In The Diversity of Bacterial Respiratory Systems, vol. 2 (in the Press). Edited by C. J. Knowles. Boca Raton, Florida: CRC Press.

McCord, J. M. \& Fridovich, I. (1969). Superoxide dismutase, an enzymic function of erythrocuprein (hemocuprein). Journal of Biological Chemistry 244, 6049-6055.

Mitchell, P. \& Moyle, J. (1967a). Acid-base titration across the membrane systems of rat-liver mitochondria. Biochemical Journal 104, 588-600.

Mitchell, P. \& Moyle, J. (1967b). Respirationdriven proton translocation in rat-liver mitochondria. Biochemical Journal 105, 1147-1162.

Pritchard, G. G. \& WimpenNy, J. W. T. (1978). Cytochrome formation, oxygen-induced proton extrusion and respiratory activity in Streptococcus faecalis var. zymogenes grown in the presence of haematin. Journal of General Microbiology 104, 15-22.

Reynafarge, B., Brand, M. D. \& Lehninger, A. L. (1976). Evaluation of the $\mathrm{H}^{+}$/site ratio of mitochondrial electron transport from rate measurements. Journal of Biological Chemistry 251, 74427451.

Ritchey, T. W. \& Seeley, H. W. (1974). Cytochromes in Streptococcus faecalis var. zymogenes grown in a haematin-containing medium. Journal of General Microbiology 85, 220-228.

Ritchey, T. W. \& Seeley, H. W. (1976). Distribution of cytochrome-like respiration in streptococci. Journal of General Microbiology 93, 195-203.

SiJPESTEIJN, A. K. (1970). Induction of cytochrome formation and stimulation of oxidative dissimilation by hemin in Streptococcus lactis and Leuconostoc mesenteroides. Antonie van Leeuwenhoek 36, 335-348.

Smalley, A. J., Jahling, P. \& VanDemark, P. J. (1968). Molar growth yields as evidence for oxidative phosphorylation in Streptococcus faecalis 10C1. Journal of Bacteriology 96, 1595-1600.

SNell, F. D. \& SNell, C. T. (1949). Colorimetric Methods of Analysis Including Some Turbidimetric and Nephelometric Methods, 3rd edn, vol. 2, pp. 882-883. Princeton, New Jersey: Van Nostrand.

Tempest, D. W. \& Neijssel, O. M. (1980). Growth yield values in relation to respiration. In Diversity of Bacterial Respiratory Systems, vol. 1 (in the Press). Edited by C. J. Knowles. Boca Raton, Florida: CRC Press. 
Van der Wiel-Korstanje, J. A. A. \& De Vries, W. (1973). Cytochrome synthesis by Bifidobacterium during growth in media supplemented with blood. Journal of General Microbiology 75, 417-419.

WhitTENBURY, R. (1960). Two types of catalase-like activity in lactic acid bacteria. Nature, London 187, 433-434.

WHITTENBURY, R. (1964). Hydrogen peroxide forma- tion and catalase activity in lactic acid bacteria. Journal of General Microbiology 35, 13-26.

Wilson, D. M., Alderete, J. F., Maloney, P. C. \& WiLson, T. H. (1976). Protonmotive force as the source of energy for adenosine 5 -triphosphate synthesis in Escherichia coli. Journal of Bacteriology 126, 327-337. 